NASA/TM-2002-211984

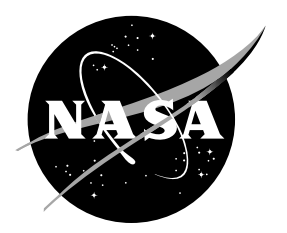

\title{
Quench Crack Behavior of Nickel-Base Disk Superalloys
}

John Gayda

Glenn Research Center, Cleveland, Ohio

Pete Kantzos

Ohio Aerospace Institute, Brook Park, Ohio

Jason Miller

University of Akron, Akron, Ohio 
Since its founding, NASA has been dedicated to the advancement of aeronautics and space science. The NASA Scientific and Technical Information (STI) Program Office plays a key part in helping NASA maintain this important role.

The NASA STI Program Office is operated by Langley Research Center, the Lead Center for NASA's scientific and technical information. The NASA STI Program Office provides access to the NASA STI Database, the largest collection of aeronautical and space science STI in the world. The Program Office is also NASA's institutional mechanism for disseminating the results of its research and development activities. These results are published by NASA in the NASA STI Report Series, which includes the following report types:

- $\quad$ TECHNICAL PUBLICATION. Reports of completed research or a major significant phase of research that present the results of NASA programs and include extensive data or theoretical analysis. Includes compilations of significant scientific and technical data and information deemed to be of continuing reference value. NASA's counterpart of peerreviewed formal professional papers but has less stringent limitations on manuscript length and extent of graphic presentations.

- TECHNICAL MEMORANDUM. Scientific and technical findings that are preliminary or of specialized interest, e.g., quick release reports, working papers, and bibliographies that contain minimal annotation. Does not contain extensive analysis.

- CONTRACTOR REPORT. Scientific and technical findings by NASA-sponsored contractors and grantees.
- CONFERENCE PUBLICATION. Collected papers from scientific and technical conferences, symposia, seminars, or other meetings sponsored or cosponsored by NASA.

- SPECIAL PUBLICATION. Scientific, technical, or historical information from NASA programs, projects, and missions, often concerned with subjects having substantial public interest.

- TECHNICAL TRANSLATION. Englishlanguage translations of foreign scientific and technical material pertinent to NASA's mission.

Specialized services that complement the STI Program Office's diverse offerings include creating custom thesauri, building customized databases, organizing and publishing research results ... even providing videos.

For more information about the NASA STI Program Office, see the following:

- Access the NASA STI Program Home Page at http://www.sti.nasa.gov

- E-mail your question via the Internet to help@sti.nasa.gov

- Fax your question to the NASA Access Help Desk at 301-621-0134

- Telephone the NASA Access Help Desk at 301-621-0390

- Write to:

NASA Access Help Desk

NASA Center for AeroSpace Information 7121 Standard Drive

Hanover, MD 21076 
NASA/TM-2002-211984

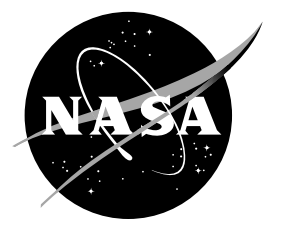

\section{Quench Crack Behavior of Nickel-Base Disk Superalloys}

John Gayda

Glenn Research Center, Cleveland, Ohio

Pete Kantzos

Ohio Aerospace Institute, Brook Park, Ohio

Jason Miller

University of Akron, Akron, Ohio

National Aeronautics and

Space Administration

Glenn Research Center 


\section{Acknowledgments}

The authors gratefully acknowledge Dr. Gil London , Naval Air Warfare Center, for providing NF3 alloy.

Available from

NASA Center for Aerospace Information 7121 Standard Drive

Hanover, MD 21076
National Technical Information Service 5285 Port Royal Road Springfield, VA 22100

Available electronically at http:/ /gltrs.grc.nasa.gov 


\title{
QUENCH CRACK BEHAVIOR OF NICKEL-BASE DISK SUPERALLOYS
}

\author{
John Gayda \\ National Aeronautics and Space Administration \\ Glenn Research Center \\ Cleveland, Ohio 44135 \\ Pete Kantzos \\ Ohio Aerospace Institute \\ Brook Park, Ohio 44142 \\ Jason Miller \\ University of Akron \\ Akron, Ohio 44325
}

\begin{abstract}
There is a need to increase the temperature capability of superalloy turbine disks to allow higher operating temperatures in advanced aircraft engines. When modifying processing and chemistry of disk alloys to achieve this capability, it is important to preserve the ability to use rapid cooling during supersolvus heat treatments to achieve coarse grain, fine gamma prime microstructures. An important step in this effort is an understanding of the key variables controlling the cracking tendencies of nickel-base disk alloys during quenching from supersolvus heat treatments. The objective of this study was to investigate the quench cracking tendencies of several advanced disk superalloys during simulated heat treatments. Miniature disk specimens were rapidly quenched after solution heat treatments. The responses and failure modes were compared and related to the quench cracking tendencies of actual disk forgings. Cracking along grain boundaries was generally observed to be operative. For the alloys examined in this study, the solution temperature not alloy chemistry was found to be the primary factor controlling quench cracking. Alloys with high solvus temperatures show greater tendency for quench cracking.
\end{abstract}

\section{Introduction}

The understanding of the physics of any process can be of great importance in the design and manufacture of a product. Nickel-base superalloys, strengthened by gamma prime precipitates, are often heat treated during the manufacturing process to control mechanical properties of the alloy. As part of the overall heat treatment process the alloy is generally quenched from elevated temperatures to increase strength. However, the thermal stresses that build up in the part during the quenching process will sometimes exceed the alloy's ultimate strength. When this occurs, cracks will form, releasing the stresses built up in the alloy but also destroying the part.

This problem is especially troublesome for modern nickel-base superalloys used in aircraft turbine disks, as the size of these forged parts can be quite large. In addition, increasing turbine disk temperatures have resulted in the use of coarser grain size to increase creep resistance, which also, unfortunately, tends to increase the likelihood of 
quench cracking during supersolvus heat treatment of the disk (Ref. 1). The term supersolvus refers to temperatures at which all gamma prime precipitates in this class of alloy are completely dissolved thereby allowing rapid grain coarsening and subsequent precipitation of fine gamma prime particles upon quenching. To minimize the formation of quench cracks, one must understand the factors that can influence crack formation under these conditions. In this experiment two key variables were examined. First, there is the solution temperature of the superalloy. That is the temperature at which the alloy is heat treated to coarsen grain size, and this can vary from alloy to alloy based on chemistry. Secondly the chemical composition of each alloy was looked at, as it affects mechanical properties such as high temperature ductility that can influence the cracking propensity of the alloy upon quenching. Studying the effect that these two variables have on the cracking propensity of a superalloy will aid in the understanding of the quench cracking process, which could allow for the design of an improved quenching process or a more crack resistant superalloy.

\section{Materials and Procedures}

A large number of small disk shaped specimens (0.9-in. diameter by 0.25 -in. thick), of three next generation nickel-base disk alloys, were machined from forgings by EDM blanking followed by low stress grinding. While the shape of the specimen was similar to disk forgings used in aircraft engines, their size was much smaller to facilitate numerous quenching trials required in this study. The three superalloys used in this experiment were ME3 (Ref. 2), NF3, and Alloy 10 (Ref. 3). They were chosen for this study, as ME3 is known to be more resistant to quench crack formation than NF3 or Alloy 10 during supersolvus heat treatment of large forgings.

As previously stated, the quench cracking problem is most severe for the coarser grain size produced by a supersolvus heat treatment. For this reason all specimens were given a pre-solution heat treatment at their respective supersolvus temperature and aircooled. This was done to produce a uniformly coarse grain size, between ASTM 6 and 7, for all alloys before running the quench experiments. The supersolvus heat treatment temperatures chosen for the three alloys were: $2140^{\circ} \mathrm{F}$ for ME3 and $2185^{\circ} \mathrm{F}$ for NF3 and Alloy 10. Each alloy was pre-solutioned at its respective supersolvus heat treatment temperature for one hour. None of the specimens cracked as a result of the air-cooling following the pre-solution treatment.

With alloy grain size set via the pre-solution heat treatment, the effects of solution temperature and alloy composition on quench cracking could now be independently studied at a constant grain size. Specimens were re-heated at various temperatures ranging from $2080^{\circ} \mathrm{F}$ to $2200{ }^{\circ} \mathrm{F}$ for 15 minutes before quenching in oil. This range of temperatures spans the range of practical solution temperatures for this class of alloys. Individual specimens were placed in the furnace on a sheet of superalloy. This was done so each specimen could be removed from the furnace by grabbing the superalloy sheet and not the specimen thereby eliminating any unwanted cooling effects introduced by direct manipulation of the specimen.

After each specimen had received the solution heat treatment it was removed from

the furnace and quenched in vacuum pump oil. Several quenching fluids were tried including water, oil, and antifreeze/water mixtures before settling on vacuum pump oil. Vacuum pump oil provided the rapid quenching rates required and also allowed 
maximum visibility of the specimen during the quench process. The oil was placed in a one-gallon can with a mesh platform in the bottom to suspend the specimen in the oil and thereby minimize cooling differences between the top and bottom of the specimen. The transfer time from furnace to quench media is very important in this experiment because the specimens are so small and loose heat very rapidly. A five second transfer time was as fast as the specimens could be quenched while still being consistent throughout the experiment. When the specimen had cooled it was visually checked for any quench cracks that might have formed.

\section{Results and Discussion}

Before presenting the experimental quench cracking results a short discussion of thermal stresses is warranted. Modeling of the specimen during the quench was done using a 2D axi-symmetric finite element model. Several assumptions were made which limited the accuracy of the analysis; nevertheless the analysis does allow one to approximate the temperature gradients along with the stress distribution in the specimen during the quench. The first and most significant approximation was the estimated heat transfer coefficient. Based on observation of glow time in oil, i.e., the time required for the specimen to stop glowing after immersion in oil, a heat transfer coefficient of $1.1 \mathrm{Btu} / \mathrm{hr}-\mathrm{F}-\mathrm{in}^{2}$ was utilized in the analysis. This number was arrived at by iteration until the predicted glow time (time for the top center location in the model to reach $120{ }^{\circ} \mathrm{F}$ ) matched the experimental glow time of 12 seconds. Other assumptions employed in the model included the following: the specimen temperature was $2140^{\circ} \mathrm{F}$ when it entered the oil, all stresses were totally elastic, and the use of constant values for heat capacity and thermal conductivity, $0.2 \mathrm{Btu} / \mathrm{lb}-\mathrm{F}$ and $1 \mathrm{Btu} / \mathrm{hr}-\mathrm{F}-\mathrm{in}$, respectively. Cooling curves generated from the model for three key locations in the specimens are plotted in Figure 1. One should note that the cooling rates approach $100^{\circ} \mathrm{F} /$ second on the skin and there is a significant thermal gradient between the interior and the surface of this specimen despite its relatively small size as seen in Figure 2. This temperature gradient produces the thermal stresses that cause quench cracking. The hoop or tangential stress distribution in the specimen is presented in Figure 3 after five seconds into the quench. The maximum thermal gradient and therefore the maximum thermal stresses are generated at this time. It should be noted that the surface of the specimen is in tension while the interior is in compression at this time. Continued cooling lowers the thermal gradient and therefore the thermal stresses. While this analysis shows the stresses are significant, the actual magnitude of the stresses is only approximate as a result of the assumptions that were previously mentioned. As expected, quench cracking initiated at the disk corners where the largest stresses were predicted.

The results from the quench testing are presented in detail in Appendix 1. Pertinent data for all alloys is summarized in Figure 4 in bar graph format. Only two temperatures are shown in the graph, they are $2170^{\circ} \mathrm{F}$ and $2200{ }^{\circ} \mathrm{F} .2140{ }^{\circ} \mathrm{F}$ is not shown because only one specimen cracked at that temperature, and no specimens cracked at $2080^{\circ} \mathrm{F}$. From this graph it would appear that there is no difference in cracking propensity of the superalloys due to chemical composition. At these temperatures all alloys behaved in a similar manner.

Figure 5 shows the cracking frequency of all alloys as a function of solution temperature. None of the specimens cracked in oil at $2080^{\circ} \mathrm{F}$, one out of 26 specimens 
cracked at $2140^{\circ} \mathrm{F}$, and at $2170^{\circ} \mathrm{F}$ and $2200^{\circ} \mathrm{F}$ about 50 percent of the specimens cracked. This leads one to conclude that solution temperature is more important than alloy chemistry with respect to quench cracking for the range of compositions studied in this paper.

The cracking observed in the quench specimens was similar to what is found in large commercial disk forgings. The quench cracking of the test specimens was all intergranular, and this is exactly what is seen in commercial forgings. The quench cracks were also near the surface at the outer edge, which is where the highest tensile stresses are located. Shown in Figure 6 is the comparison of intergranular cracking in Alloy 10, between a full-scale forging and one of the test specimens.

It should be noted that quenching even from the highest temperature did not cause cracks in all of the specimens. Furthermore, many samples survived multiple quenches before cracking. This implies that the formation of quench cracks is a complex and perhaps stochastic process controlled by many variables. In order to study the evolution of cracking, quenched disks that did not show any cracking were sectioned and examined by metallography. Microscopic damage, in the form of small subsurface intergranular cracks, was observed in many of the visually un-cracked samples. The extent of damage also seemed to increase with temperature. Shown in Figure $7 \mathrm{a}$ and $7 \mathrm{~b}$ is Alloy 10 specimens after quenching from $2140^{\circ} \mathrm{F}$ and $2170^{\circ} \mathrm{F}$. One can see evidence of micro cracking at grain boundaries at $2170^{\circ} \mathrm{F}$, which is absent at $2140{ }^{\circ} \mathrm{F}$. This microscopic cracking has also been observed in large forgings as shown in Figure 7c for an ME3 forging.

While chemistry differences between the three alloys were significant, all were high gamma prime content alloys (50 to 60\%), typical of next generation disk alloys. Furthermore, all the alloys in this study had similar grain size. It appears that solvus temperature was the most important factor affecting quench crack tolerance, not alloy chemistry per say. However, alloy chemistry does change solvus temperature and therefore has an important indirect role on quench crack propensity. ME3 has a lower solvus temperature than Alloy 10 or NF3 and is therefore less likely to quench crack when it is given a "commercial" supersolvus solution treatment followed by an aggressive quench, Figure 8.

\section{Summary and Conclusions}

Quenching experiments on three next generation turbine disk alloys, ME3, NF3, and Alloy 10, were run on miniature disk specimens. Although there are significant differences in the cooling history between these specimens and larger, commercial forgings, these tests were successful in generating quench cracks similar to what is seen in the large forgings.

The design of this study allowed a clear separation of chemistry effects and solution temperature for coarse grain microstructures, ASTM 6 to 7. Based on the results of this study, it appeared that solution temperature, not alloy chemistry, was the primary factor controlling quench cracking of these alloys. This data suggests that alloy designers

can increase alloying content to approach the strength levels of Alloy 10 or NF3 without increasing the risk of quench cracking by maintaining a lower solvus temperature similar to that of ME3. 


\section{References}

1. T.P. Gabb et al., "The Tensile Properties of Advanced Nickel-Base Disk Superalloy During Quenching Heat Treatments," NASA/TM-2001-211218, October 2001.

2. T.P. Gabb, J. Telesman, P. Kantzos, and K. O'Connor, "Characterization of the Temperature Capabilities of Advanced Disk Alloy ME3," NASA/TM-2002211796, August 2002.

3. S.K. Jain, "High OPR Core Material (AoI 4.2.4), Regional Engine Disk Development," AST Regional Disk Program Final Report, NAS3-27720, November 1999. 


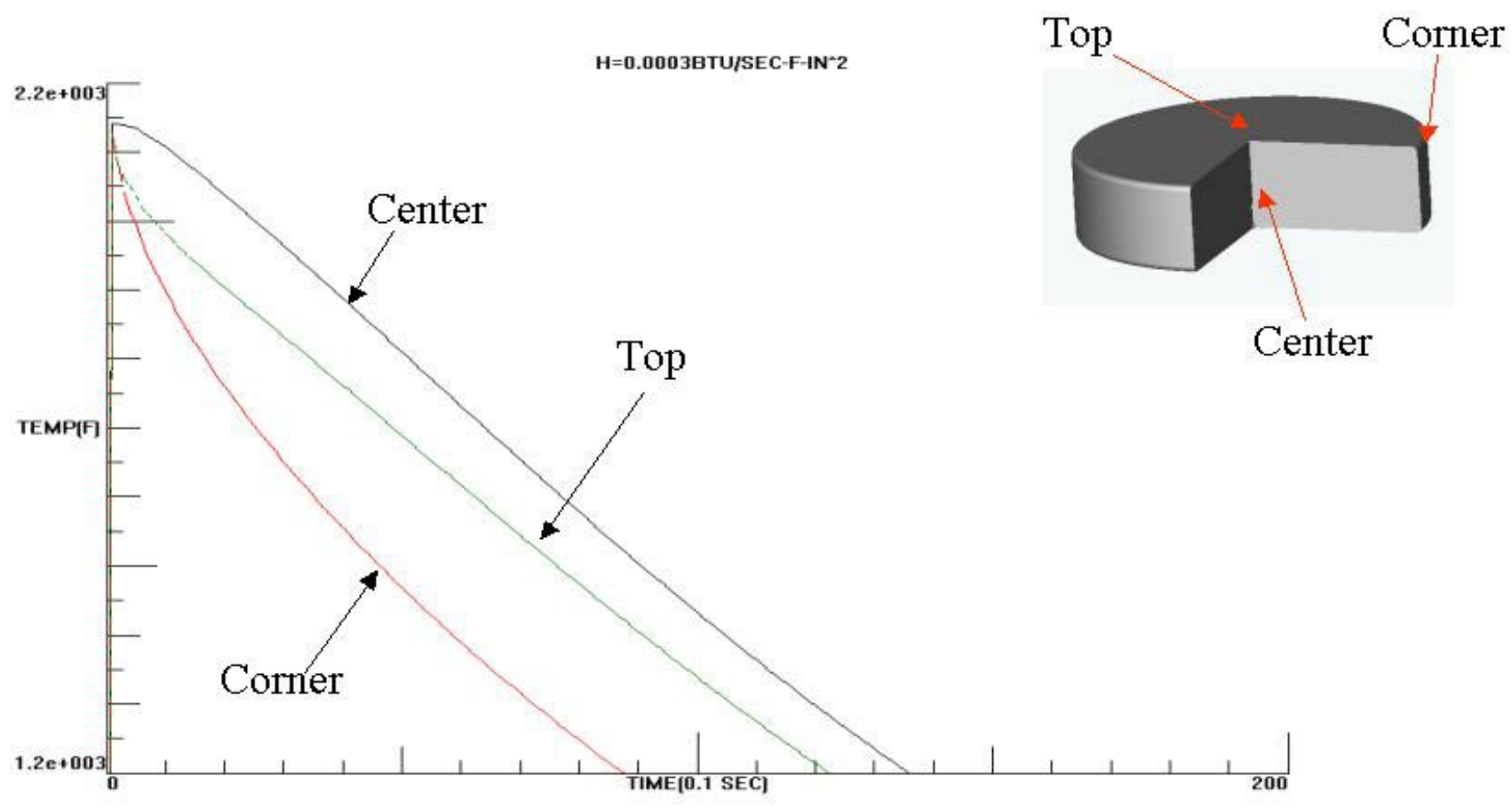

Figure 1. Analytical cooling curves for selected locations in quench specimens.

TEMPERATURE DISTRIBUTION AFTER ऽ SECONDS Temperature
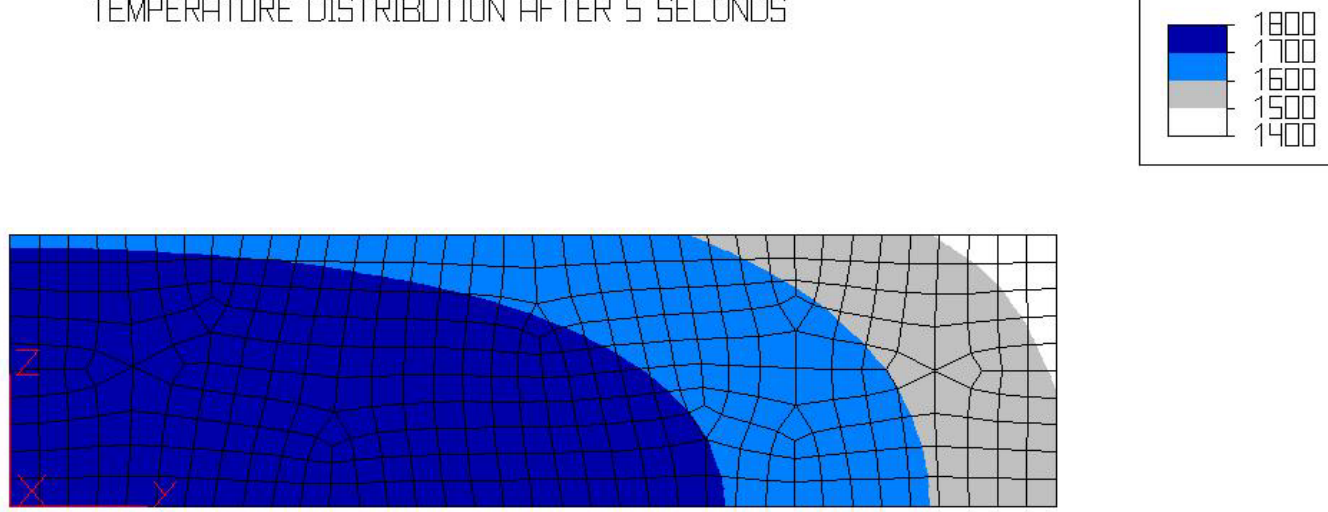

Figure 2. Temperature distribution in quench specimen. 
MHXIMLM QUENLH STRESS (PSI)

5 SEEDNDS INTO QUENCH
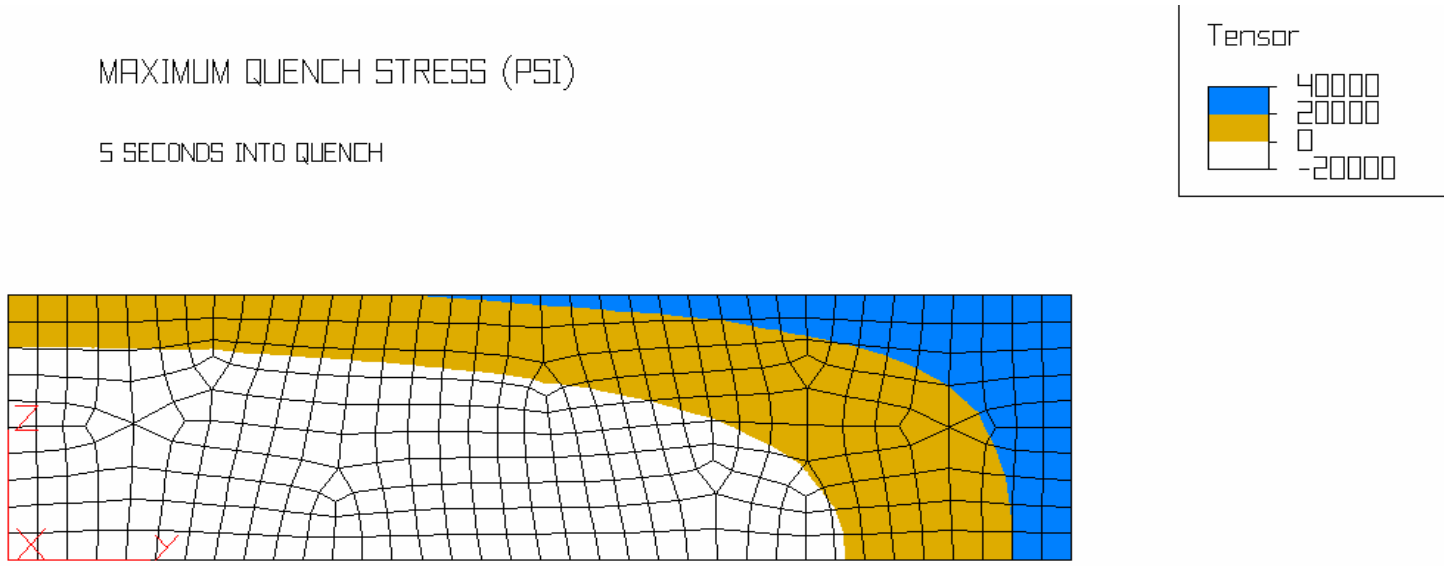

Figure 3. Hoop stress distribution in quench specimen. Note tensile component on surface and compressive component at interior of specimen.

CRACK FREQUENCY FOR INDIVIDUAL ALLOYS COARSE GRAIN MICROSTRUCTURES QUENCHED IN OIL FROM VARIOUS SOLUTION TEMPERATURES

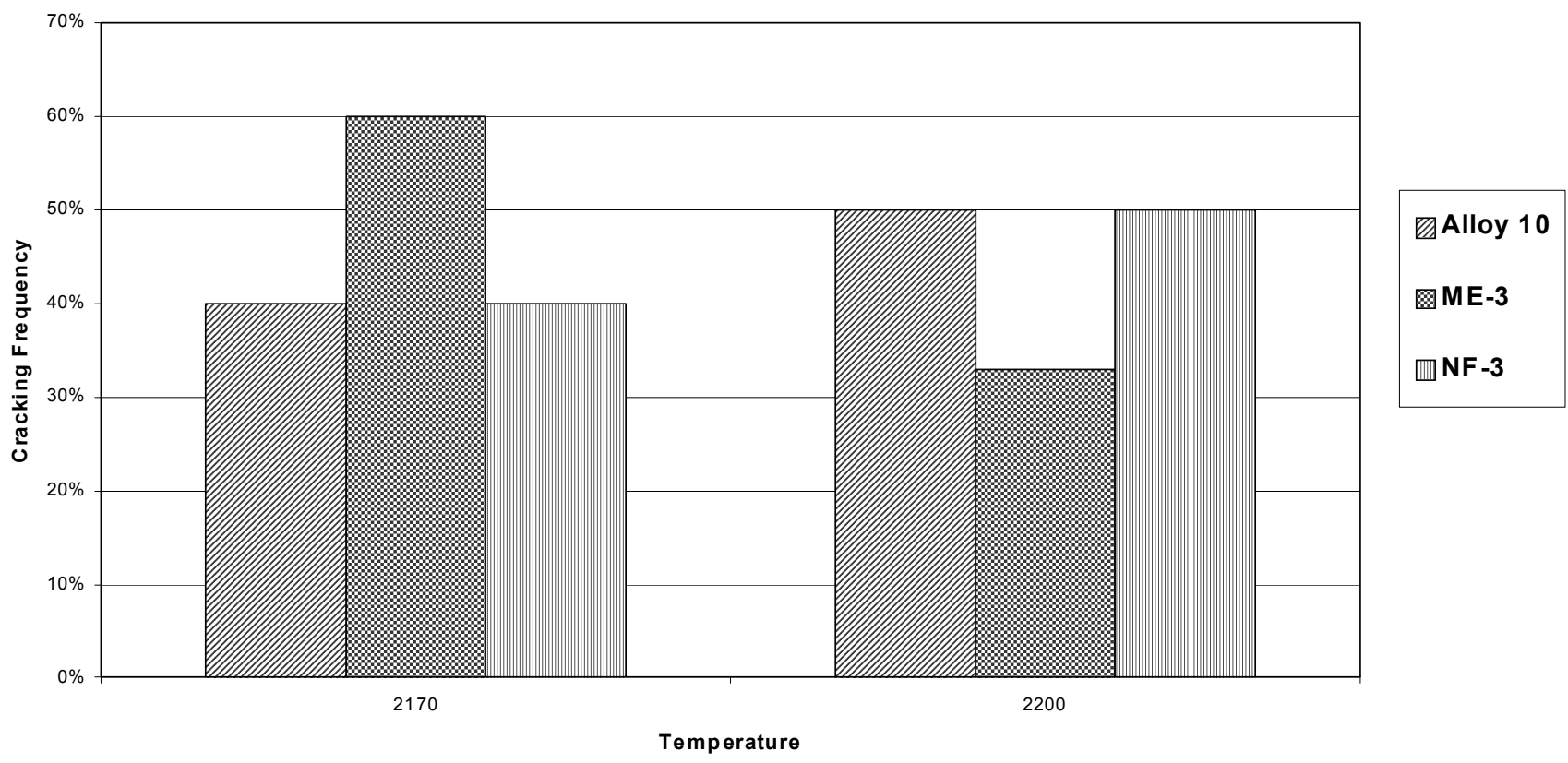

Figure 4. Quench crack frequency for each alloy at 2170 and $2200^{\circ} \mathrm{F}$. 
QUENCH CRACK FREQUENCY FOR ALL ALLOYS COARSE GRAIN MICROSTRUCTURE QUENCHED IN OIL

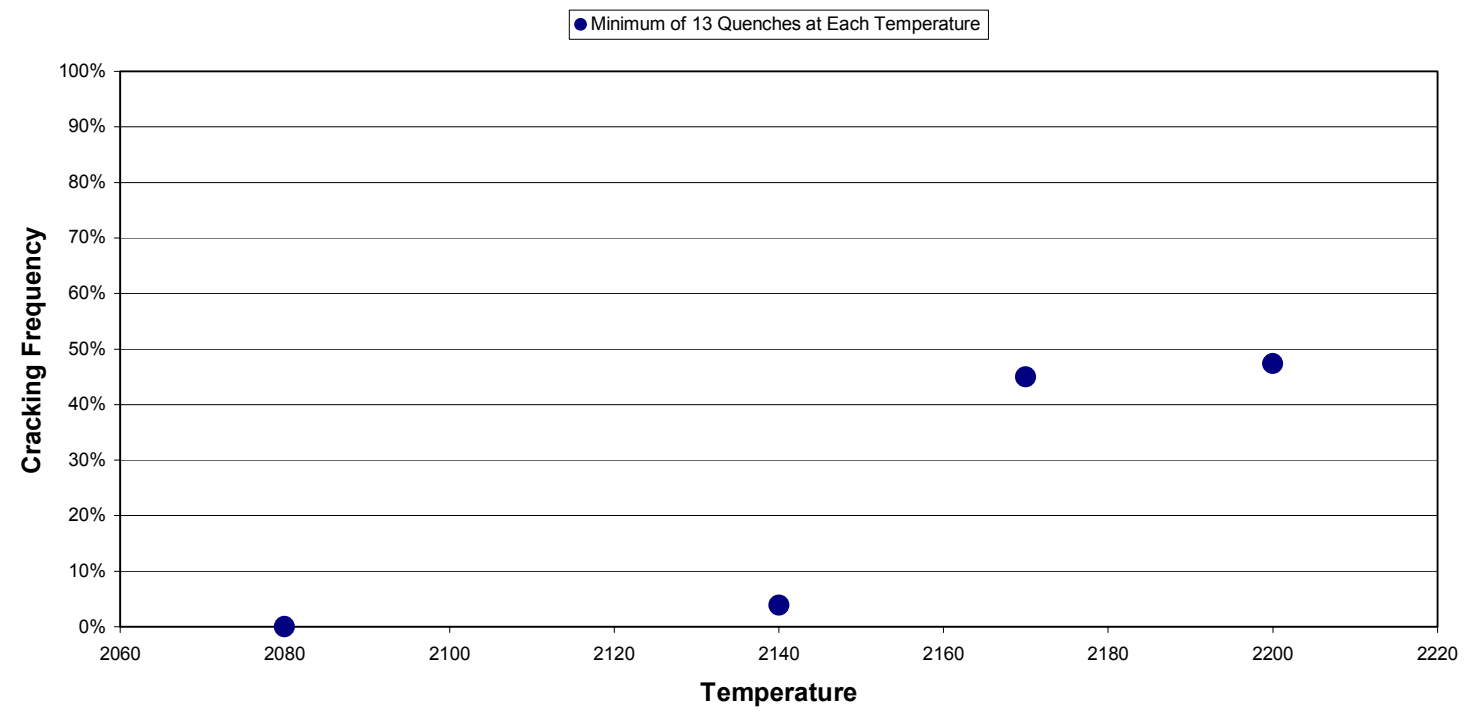

Figure 5. Quench crack frequency for all alloys at all solution temperatures.

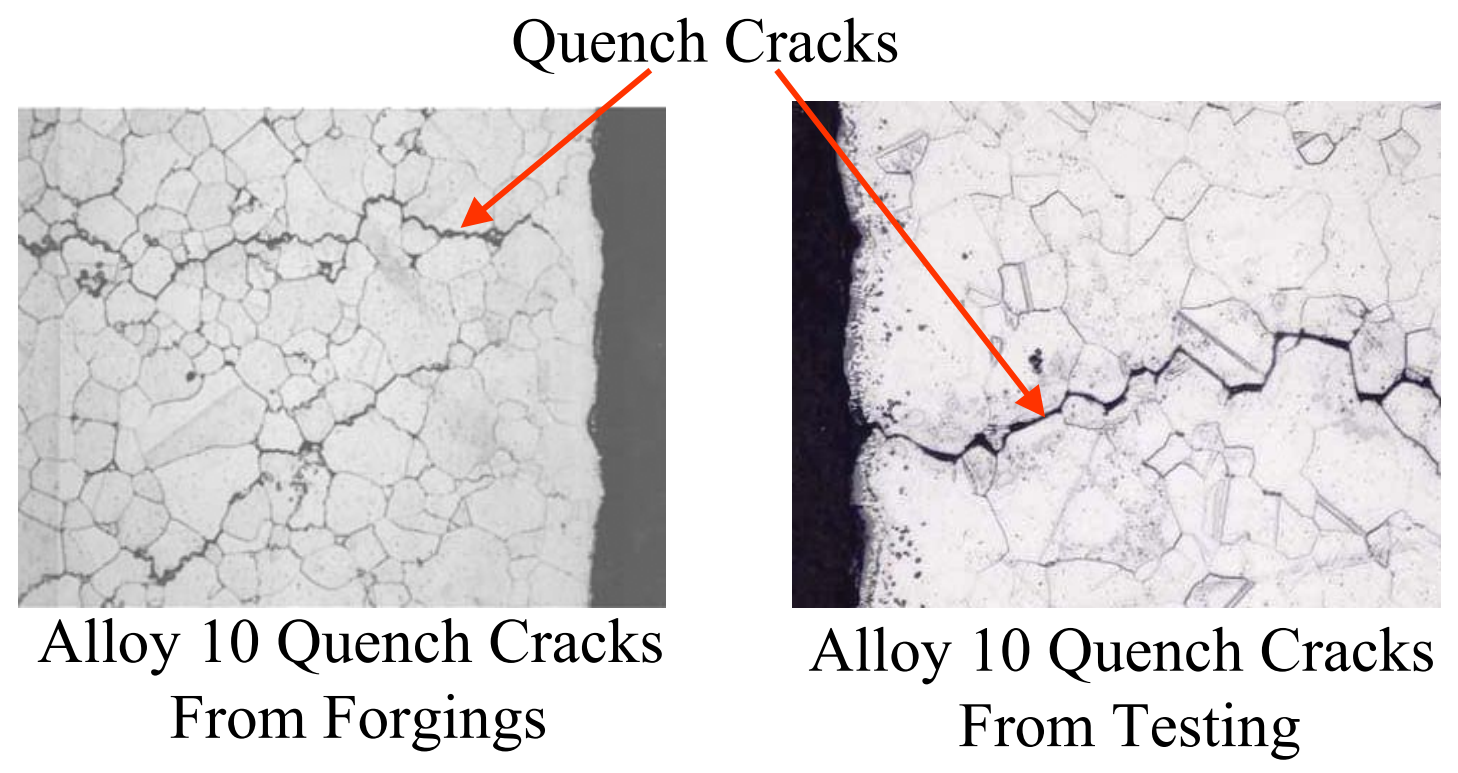

Figure 6. Comparison of quench cracks in Alloy 10 forgings and quench specimens. 


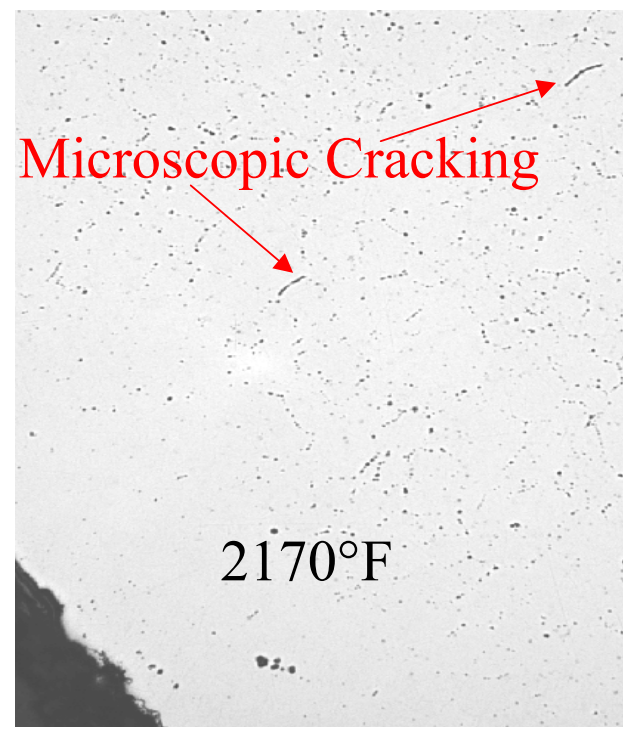

a)

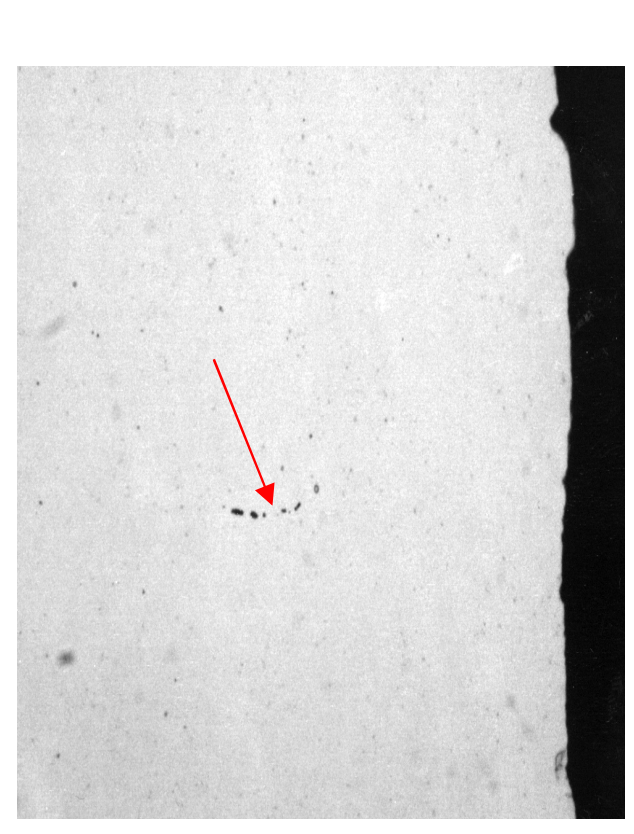

c)

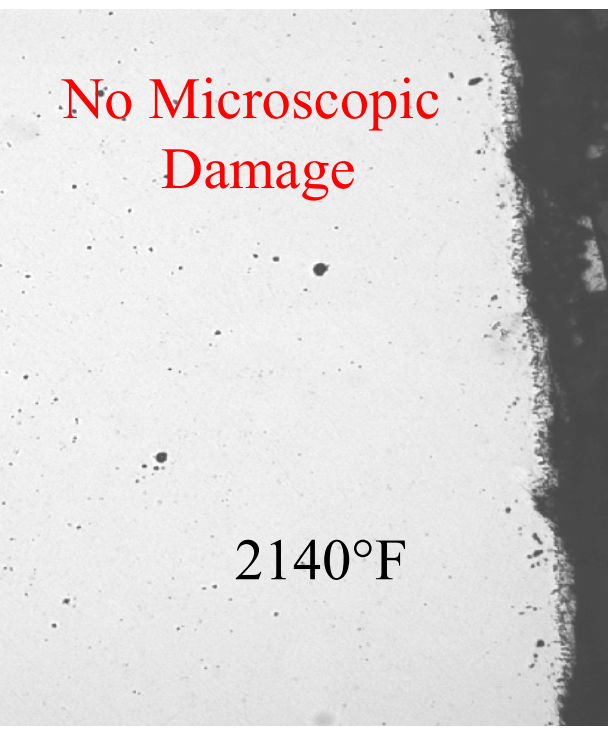

b)

Figure 7. Comparison of microcracking: a) in Alloy 10 at $2170{ }^{\circ} \mathrm{F}$, b) Alloy 10 at $2140^{\circ} \mathrm{F}$, and c) ME3 full-scale disk. 


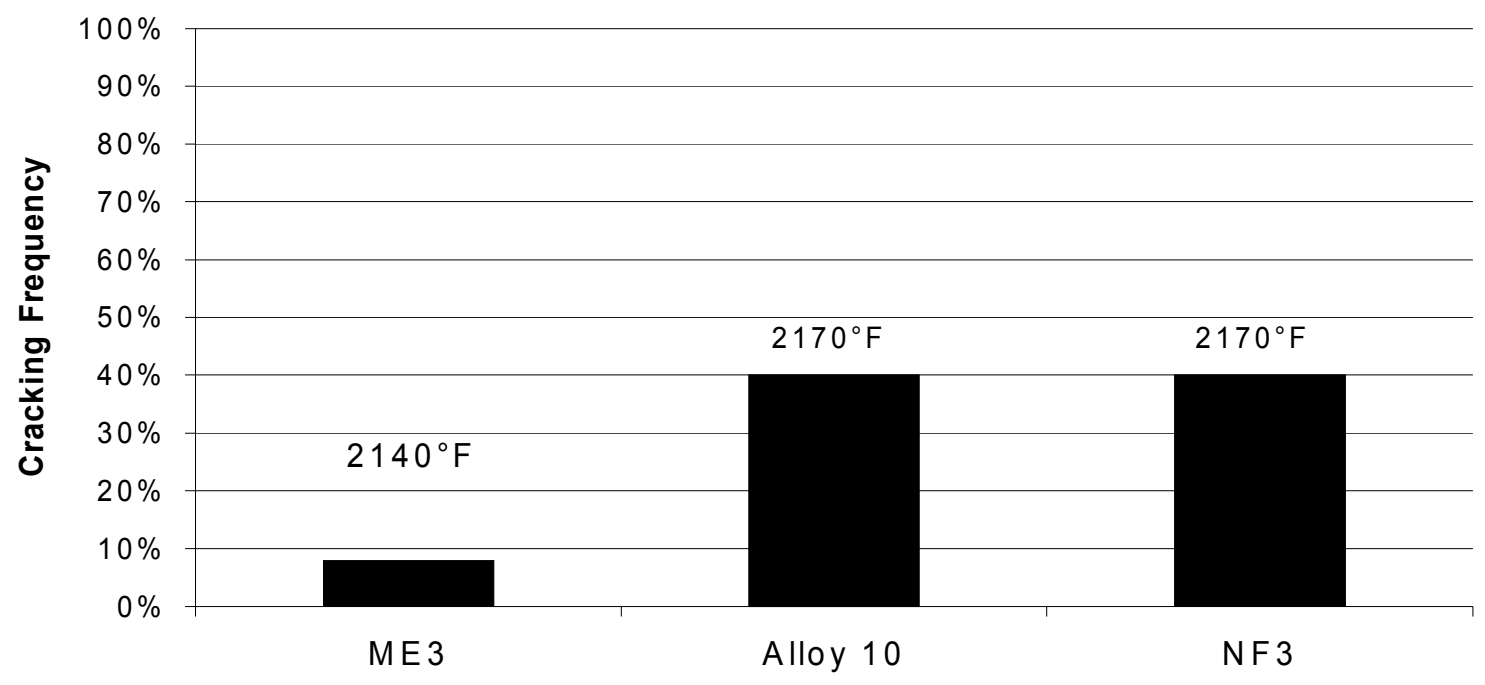

Figure 8. Cracking frequencies of alloys at their respective solvus Temperatures 


\begin{tabular}{|c|c|c|c|c|c|c|c|c|}
\hline \multicolumn{9}{|c|}{ APPENDIX 1 - QUENCH CRACK DATA } \\
\hline ALLOY 10 & TEMP(F) & CRACK & ME3 & TEMP(F) & CRACK & NF3 & TEMP(F) & CRACK \\
\hline $10 \mathrm{~A}-1$ & 2080 & $\mathrm{~N}$ & $3 D-1$ & 2080 & $\mathrm{~N}$ & $82 A-1$ & 2080 & $\mathrm{~N}$ \\
\hline $10 \mathrm{~A}-2$ & 2080 & $\mathrm{~N}$ & $3 \mathrm{D}-2$ & 2080 & $\mathrm{~N}$ & $82 A-2$ & 2080 & $\mathrm{~N}$ \\
\hline $10 A-3$ & 2080 & $\mathrm{~N}$ & & & & & & \\
\hline $10 \mathrm{~A}-4$ & 2080 & $\mathrm{~N}$ & $3 \mathrm{~K}-1$ & 2140 & $\mathrm{~N}$ & $82 A-3$ & 2140 & $\mathrm{~N}$ \\
\hline $10 A-6$ & 2080 & $\mathrm{~N}$ & $3 \mathrm{~K}-2$ & 2140 & $\mathrm{~N}$ & $82 A-4$ & 2140 & $\mathrm{~N}$ \\
\hline $10 \mathrm{~A}-7$ & 2080 & $\mathrm{~N}$ & $3 \mathrm{~K}-3$ & 2140 & $\mathrm{~N}$ & $82 \mathrm{D}-1$ & 2140 & $\mathrm{~N}$ \\
\hline \multirow[t]{2}{*}{ 10B-1 } & 2080 & $\mathrm{~N}$ & $3 \mathrm{~K}-4$ & 2140 & $\mathrm{~N}$ & $82 \mathrm{D}-2$ & 2140 & $\mathrm{~N}$ \\
\hline & & & $3 \mathrm{~K}-5$ & 2140 & $\mathrm{~N}$ & $82 \mathrm{D}-3$ & 2140 & $\mathrm{~N}$ \\
\hline 10B-7 & 2140 & $\mathrm{~N}$ & $3 D-3$ & 2140 & $\mathrm{~N}$ & $82 \mathrm{D}-4$ & 2140 & $\mathrm{~N}$ \\
\hline 10D-1 & 2140 & $\mathrm{~N}$ & $3 \mathrm{D}-4$ & 2140 & $\mathrm{~N}$ & $82 \mathrm{D}-5$ & 2140 & $\mathrm{~N}$ \\
\hline 10D-2 & 2140 & $\mathrm{~N}$ & $3 \mathrm{I}-1$ & 2140 & $\mathrm{~N}$ & & & \\
\hline 10D-3 & 2140 & $\mathrm{~N}$ & $3 \mathrm{I}-2$ & 2140 & $\mathrm{~N}$ & $82 \mathrm{E}-1$ & 2170 & $Y$ \\
\hline \multirow[t]{2}{*}{ 10D-4 } & 2140 & $\mathrm{~N}$ & $3 \mathrm{I}-3$ & 2140 & $\mathrm{~N}$ & $82 \mathrm{E}-2$ & 2170 & $\mathrm{~N}$ \\
\hline & & & $3 \mathrm{I}-4$ & 2140 & $\mathrm{~N}$ & $82 E-3$ & 2170 & $\mathrm{~N}$ \\
\hline 10D-5 & 2170 & $\mathrm{~N}$ & $3 \mathrm{I}-5$ & 2140 & $Y$ & $82 E-4$ & 2170 & $\mathrm{Y}$ \\
\hline 10D-6 & 2170 & $\mathrm{Y}$ & & & & $82 E-5$ & 2170 & $\mathrm{~N}$ \\
\hline 10D-7 & 2170 & $\mathrm{~N}$ & $3 \mathrm{M}-1$ & 2170 & $Y$ & & & \\
\hline $10 \mathrm{E}-1$ & 2170 & $\mathrm{~N}$ & $3 \mathrm{M}-2$ & 2170 & $Y$ & $82 A-5$ & 2200 & $\mathrm{Y}$ \\
\hline $10 \mathrm{E}-2$ & 2170 & $\mathrm{Y}$ & $3 \mathrm{M}-3$ & 2170 & $\mathrm{~N}$ & $82 C-1$ & 2200 & $\mathrm{Y}$ \\
\hline $10 \mathrm{E}-3$ & 2170 & $\mathrm{~N}$ & $3 \mathrm{M}-4$ & 2170 & $Y$ & $82 \mathrm{C}-2$ & 2200 & $Y$ \\
\hline 10E-4 & 2170 & $\mathrm{~N}$ & $3 \mathrm{M}-5$ & 2170 & $\mathrm{~N}$ & $82 C-3$ & 2200 & $\mathrm{~N}$ \\
\hline 10E-5 & 2170 & $Y$ & & & & $82 \mathrm{C}-4$ & 2200 & $\mathrm{~N}$ \\
\hline 10E-6 & 2170 & $\mathrm{Y}$ & $3 D-5$ & 2200 & $\mathrm{~N}$ & $82 C-5$ & 2200 & $Y$ \\
\hline \multirow[t]{2}{*}{ 10E-7 } & 2170 & $\mathrm{~N}$ & $3 F-1$ & 2200 & $Y$ & & & \\
\hline & & & $3 F-2$ & 2200 & $Y$ & & & \\
\hline $10 A-5$ & 2200 & $Y$ & $3 F-3$ & 2200 & $\mathrm{~N}$ & & & \\
\hline 10B-2 & 2200 & $\mathrm{Y}$ & $3 F-4$ & 2200 & $\mathrm{~N}$ & & & \\
\hline 10B-3 & 2200 & $\mathrm{~N}$ & $3 F-5$ & 2200 & $\mathrm{~N}$ & & & \\
\hline 10B-4 & 2200 & $Y$ & & & & & & \\
\hline 10B-5 & 2200 & $\mathrm{~N}$ & & & & & & \\
\hline 10B-6 & 2200 & $\mathrm{~N}$ & & & & & & \\
\hline
\end{tabular}




\begin{tabular}{|c|c|c|c|}
\hline \multicolumn{3}{|c|}{ REPORT DOCUMENTATION PAGE } & $\begin{array}{l}\text { Form Approved } \\
\text { OMB No. 0704-0188 }\end{array}$ \\
\hline \multicolumn{4}{|c|}{$\begin{array}{l}\text { Public reporting burden for this collection of information is estimated to average } 1 \text { hour per response, including the time for reviewing instructions, searching existing data sources, } \\
\text { gathering and maintaining the data needed, and completing and reviewing the collection of information. Send comments regarding this burden estimate or any other aspect of this } \\
\text { collection of information, including suggestions for reducing this burden, to Washington Headquarters Services, Directorate for Information Operations and Reports, } 1215 \text { Jefferson } \\
\text { Davis Highway, Suite 1204, Arlington, VA 22202-4302, and to the Office of Management and Budget, Paperwork Reduction Project (0704-0188), Washington, DC 20503. }\end{array}$} \\
\hline 1. AGENCY USE ONLY (Leave blank) & \begin{tabular}{|l} 
2. REPORT DATE \\
November 2002
\end{tabular} & 3. & $\begin{array}{l}\text { D DATES COVERED } \\
\text { echnical Memorandum }\end{array}$ \\
\hline $\begin{array}{l}\text { 4. TITLE AND SUBTITLE } \\
\text { Quench Crack Behavior of } 1\end{array}$ & \multicolumn{2}{|c|}{ Quench Crack Behavior of Nickel-Base Disk Superalloys } & 5. FUNDING NUMBERS \\
\hline \multicolumn{4}{|c|}{ John Gayda, Pete Kantzos, and Jason Miller } \\
\hline \multicolumn{3}{|c|}{$\begin{array}{l}\text { National Aeronautics and Space Administration } \\
\text { John H. Glenn Research Center at Lewis Field } \\
\text { Cleveland, Ohio } 44135-3191\end{array}$} & $\begin{array}{l}\text { 8. PERFORMING ORGANIZATION } \\
\text { REPORT NUMBER } \\
\text { E-13654 }\end{array}$ \\
\hline \multicolumn{3}{|c|}{ 9. SPONSORING/MONITORING AGENCY NAME(S) AND ADDRESS(ES) } & $\begin{array}{l}\text { 10. SPONSORING/MONITORING } \\
\text { AGENCY REPORT NUMBER } \\
\text { NASA TM-2002-211984 }\end{array}$ \\
\hline
\end{tabular}

John Gayda, NASA Glenn Research Center; Pete Kantzos, Ohio Aerospace Institute, 22800 Cedar Point Road, Brook Park, Ohio 44142; Jason Miller, University of Akron, Akron, Ohio 44325. Responsible person, John Gayda, organization code 5120, 216-433-3273.

\begin{tabular}{|l|l}
\hline 12a. DISTRIBUTION/AVAILABILITY STATEMENT & 12b. DISTRIBUTION CODE
\end{tabular}

Unclassified - Unlimited

Subject Category: $26 \quad$ Distribution: Nonstandard

Available electronically at http://gltrs.grc.nasa.gov

This publication is available from the NASA Center for AeroSpace Information, 301-621-0390.

13. ABSTRACT (Maximum 200 words)

There is a need to increase the temperature capability of superalloy turbine disks to allow higher operating temperatures in advanced aircraft engines. When modifying processing and chemistry of disk alloys to achieve this capability, it is important to preserve the ability to use rapid cooling during supersolvus heat treatments to achieve coarse grain, fine gamma prime microstructures. An important step in this effort is an understanding of the key variables controlling the cracking tendencies of nickel-base disk alloys during quenching from supersolvus heat treatments. The objective of this study was to investigate the quench cracking tendencies of several advanced disk superalloys during simulated heat treatments. Miniature disk specimens were rapidly quenched after solution heat treatments. The responses and failure modes were compared and related to the quench cracking tendencies of actual disk forgings. Cracking along grain boundaries was generally observed to be operative. For the alloys examined in this study, the solution temperature not alloy chemistry was found to be the primary factor controlling quench cracking. Alloys with high solvus temperatures show greater tendency for quench cracking.

14. SUBJECT TERMS

Superalloy disk heat treatment

17. SECURITY CLASSIFICATION OF REPORT

Unclassified

\section{SECURITY CLASSIFICATION OF THIS PAGE \\ Unclassified}

15. NUMBER OF PAGES

17

16. PRICE CODE

20. LIMITATION OF ABSTRACT 